\title{
THE EFFECT OF DIFFERENT AGROTECHNICAL LEVELS ON WEED INFESTATION IN CROPS OF NAKED AND HUSKED VARIETIES OF OAT (Avena sativa L.)
}

\author{
Sylwia Andruszczak, Ewa Kwiecińska-Poppe, Piotr Kraska, Edward Pałys
}

\author{
Department of Agricultural Ecology, University of Life Sciences in Lublin \\ Akademicka 13, 20-950 Lublin, Poland \\ e-mail: sylwia.andruszczak@up.lublin.pl
}

Received: 6.05 .2010

\begin{abstract}
The present study was carried out in the period 20072009 in the Experimental Farm in Bezek near the city of Chełm. The aim of the investigation was to compare weed infestation of the husked (Krezus) and naked (Cacko) oat cultivars cultivated under conditions of different weed control treatments. The following weed control levels were compared: A - control object; $\mathrm{B}$ - harrowing twice; $\mathrm{C}$ - application of the herbicide Mustang 306 SE; D - herbicide Mustang 306 SE + foliar fertilizer Insol 3; E - herbicide Mustang 306 SE + two foliar fertilizers: Insol 3 and FoliCare 18:18:18.

The husked oat cv. Krezus was more competitive against weeds. Number of dicotyledonous weeds and of monocotyledonous weeds, total weeds, and air-dry weight of above-ground parts of weeds in the crop of this cultivar were all significantly lower compared to the naked cv. Cacko. From the group of dicotyledonous species, Chenopodium album, Galinsoga parviflora, Matricaria maritima ssp. inodora, Polygonum aviculare, and Stellaria media were the dominant species in the crops of the oat varieties under investigation, whereas among the monocotyledonous species Echinochloa crus-galli, Setaria pumila, Apera spica-venti, and Elymus repens occurred in greatest numbers. The application of the herbicide Mustang 306 SE decreased the number of dicotyledonous weeds and air-dry weight of weeds, compared to the treatment in which mechanical weed control had been used.
\end{abstract}

Key words: naked oat, husked oat, weed infestation, weed control level

\section{INTRODUCTION}

The existing research on weed infestation of spring cereals shows that they are generally less susceptible to weed pressure than winter cereals $(\mathrm{Za}$ wiślak and Grejner, 1988). At the same time, oats compete better against weeds than spring barley or spring wheat. Their advantage over other cereals are justified by early sowing time, a dynamic increase in above-ground and root mass as well as rich foliage that shades well the soil (W a n i c, 1997; B u d z y ń s k i, 1999; Deryło et al., 2003; A damiak and Adamiak, 2004; Idziak et al. 2007).

According to I d z i a k et al. (2007), under conditions of high level tillage, chemical weed control in oat crops can be dispensed with. It is extremely important since, out of concern for the natural environment, efforts are now undertaken to reduce the use of chemical plant protection agents. Les zczyńska (2007) as well as Sułek and Brzóska (2007) are of opinion that, in weed control treatments used in oat crops, mechanical crop protection is of great importance, as oats are sensitive to most herbicides. However, at the initial growth stages (tillering and shooting) oats promote the abundant emergence of early germinating weeds that germinate in low temperatures (A d miak and Zawiślak, 1991). That is why, under conditions of strong weed infestation of crops, the application of herbicides is recommended as auxiliary treatment (L e s z c z y ń s k a, 2002; 2007). The selection of an appropriate herbicide is very important, since an inappropriate chemical agent can cause phytotoxicity, thereby inhibiting plant growth ( $\mathrm{S} \mathrm{k} \mathrm{r} \mathrm{z} \mathrm{y} \mathrm{p} \mathrm{-}$ czak and Pudełko，2001; Krawczyk and Stachecki, 2003).

Most papers on weed infestation in oat crops relate only to the husked form, but there are few studies which also cover the naked forms of this plant (Sadowski and Rychcik, 2008). The aim of the presented study was to compare weed infestation in crops of the naked and husked oat varieties grown under conditions of different weed control treatments. 


\section{MATERIALS AND METHODS}

The present field experiment was conducted in the period 2007-2009 in the Bezek Experimental Farm near the city of Chełm. The experimental field was located on incomplete podzolic soil lying on marl substrate with the granulometric composition of loamy sand. This soil is classified as soil class $\mathrm{IVb}$ and good rye complex. It was characterized by slightly acidic $\mathrm{pH}(\mathrm{pH}$ in $1 \mathrm{~mol} \mathrm{KCl} 6.0)$, high phosphorus content $\left(74.6 \mathrm{mg} \times \mathrm{kg}^{-1}\right)$, average potassium content $\left(99.6 \mathrm{mg} \times \mathrm{kg}^{-1}\right)$, and low magnesium content $\left(22.0 \mathrm{mg} \times \mathrm{kg}^{-1}\right)$. The humus content was $1.2 \%$.

Tillage was done following generally accepted agricultural practice recommendations. Winter triticale was a forecrop for oat crops. Oat (Avena sativa L.) seeds were sown in the 3 rd decade of April at an amount of 500 seeds per $1 \mathrm{~m}^{2}$. The following doses of mineral fertilizers were applied (in $\mathrm{kg}$ of pure component per hectare): N-80; P-26.2; K-66.4.

The two-factor field experiment was set up according to a randomized block design, in 4 replicates. The plot area was $15 \mathrm{~m}^{2}$. The experiment included two oat varieties (naked oats var. Cacko and husked oats var. Krezus) and five weed control levels: a) control object; b) harrowing twice at the tillering stage; c) application of the herbicide Mustang 306 SE; d) herbicide Mustang $306 \mathrm{SE}+$ foliar fertilizer Insol 3; e) herbicide Mustang $306 \mathrm{SE}+$ foliar fertilizers Insol 3 and FoliCare 18:18:18. The herbicide Mustang $306 \mathrm{SE}$ (florasulam - a compound from the group of triazolopyrimidines - $6.25 \mathrm{~g} \times 1$; 2,4-D EHE - a compound from the group of phenoxy acids $-300 \mathrm{~g} \times 1$ ) was applied at the tillering stage (BBCH 23-29), at a dose of $0.41 \times$ ha. Spraying with the foliar fertilizers, Insol 3 and FoliCare 18:18:18, was done twice - at the tillering stage (BBCH 23-29) and at the shooting stage (BBCH 33-39), at a dose of $11 \times$ ha and $20 \mathrm{~kg} \times$ ha, respectively. The chemical composition of the fertilizers is shown in Table 1.

Weed infestation of the crop was determined using the quantitative gravimetric method about 2 weeks before the harvest of oats. Number of weeds, weed species composition and air-dry weight of the above-ground parts of weeds were determined based on the sampling sites marked out by a $1 \mathrm{~m}$ x $0.25 \mathrm{~m}$ frame, in four randomly selected places in each plot. The obtained results were statistically processed using the variance analysis method and least significant differences were calculated using Tukey's confidence half-intervals with a $5 \%$ risk of error.

Table 1

Chemical composition of foliar fertilizers (\%)

\begin{tabular}{cccccccccccc}
\hline Foliar fertilizer & $\mathrm{N}$ & $\mathrm{P}$ & $\mathrm{K}$ & $\mathrm{Mg}$ & $\mathrm{S}$ & $\mathrm{B}$ & $\mathrm{Cu}$ & $\mathrm{Fe}$ & $\mathrm{Mn}$ & $\mathrm{Mo}$ & $\mathrm{Zn}$ \\
\hline Insol 3 & 11.5 & - & - & 2.84 & - & 0.28 & 0.56 & 1.20 & 1.68 & 0.01 & 1.12 \\
FoliCare 18:18:18 & 18.0 & 18.1 & 18.0 & 1.5 & 7.2 & 0.02 & 0.10 & 0.20 & 0.10 & 0.01 & 0.02 \\
\hline
\end{tabular}

\section{RESULTS AND DISCUSSION}

One of the methods of weed infestation reduction in crop plants is the selection of varieties showing greater competitiveness against weeds. The importance of oat varieties in weed management is not well-recognised. Assessing the susceptibility of husked oat varieties to weed pressure, $\mathrm{A} \mathrm{d} \mathrm{a} \mathrm{mi} \mathrm{a} \mathrm{k} \mathrm{and}$ A d a miak (2004) showed that the variety Boryna competed better with weeds at the early growth stages (tillering), whereas the variety Kwant demonstrated greater competitiveness when the crop was at full growth (flowering). In the present experiment, irrespective of the weed control level, the husked variety Krezus was more competitive against weeds, which was probably attributable to plant height and high panicle density per unit area. Number of dicotyledonous weeds and of monocotyledonous weeds, total weeds, and airdry weight of above-ground parts of weeds in the crop of this variety were all significantly lower compared to the naked variety Cacko (Table 2).

A total of 44 weed species were identified in the oat crop - 39 from the group of dicotyledonous weeds and 5 monocotyledonous species. Only single specimens occurred in the case of most of the taxa (Table 3 ). The floristic composition primarily comprised the following taxa: Chenopodium album, Galinsoga parviflora, Matricaria maritima ssp. inodora, Polygonum avicula$r e$, and Stellaria media from the group of dicotyledonous weeds, while Echinochloa crus-galli, Setaria pumila, Apera spica-venti, and Elymus repens from monocotyledonous species. The abovementioned species were classified as dominant weeds, since they accounted respectively for $84.0 \%$ and $87.9 \%$ of the total number of weeds in the crops of the varieties Cacko and Krezus.

The weed community in the crop of the naked variety Cacko numbered 38 species, whereas the weed 
flora of the husked variety Krezus comprised a total of 35 species (Table 3). As many as 24 species from the group of dicotyledonous weeds and all monocotyledonous weeds ( 5 species) were common to the crops of both varieties. In addition, 9 taxa appeared in the naked oat crop, among others Veronica agrestis, Stachys palustris, Sonchus arvensis, and Cirsium arvense. At the same time, species such as: Veronica persica, Centaurea cyanus, Convolvulus arvensis, Anthemis arvense, Anchusa arvensis, and Triforium pratense were sporadically noted in the plots with husked oats. Analysing the species composition of the weeds colonising the oat crops, it can be concluded that, in the light of literature data, it was typical of this cereal grain (D e ryło etal. 2003; V a n hala and Pietola, 2003; S a d ow ski and R y chcik, 2008).

The numbers of weeds in the oat crop was dependent on the weed control level. Harrowing twice during the plant growth period reduced the number of dicotyledonous weeds, monocotyledonous weeds, and total weeds by $6 \%, 41 \%$ and $25 \%$, respectively, compared to the control object (Table 4). The results of the studies of S a d ow s ki and R y c h c i k (2008) prove the beneficial effect of mechanical plant protection on weed infestation of oat crops. These authors found a $75 \%$ reduction in the number of weeds at the milk maturity stage in the plot which had been harrowed twice, compared to the spring evaluation. But weed biomass, expressed as air-dry weight of weeds, gives fuller information on the competitiveness of oats against weeds. In the present experiment, this parameter of weed infestation evaluation did not change under the influence of mechanical weed control (Table 4).

The number of weed species in the oat crop in which mechanical weed control was used was similar to the control object (Table 5). In the treatment with harrowing twice, the presence of 28 dicotyledonous and 5 monocotyledonous species was found, whereas in the control plots 31 dicotyledonous and 5 monocotyledonous species occurred. Mechanical control of dicotyledonous weeds in the oat crop completely eliminated 4 species (Stachys palustris, Mentha arvense, Anthemis arvensis, and Papaver rhoeas) and reduced the population of 11 taxa, compared to the control object. At the same time, 14 species increased their proportion in the weed community. In the group of monocotyledonous weeds, the same species were predominant in both treatment combinations, but in the object with mechanical protection Echinochloa crus-galli and Setaria pumila occurred with twice lower intensity.

In line with expectations and the results of studies of other authors, the weed-killing effect of the applied herbicide was higher than that of mechanical weed control (Hyvönen and Salonen, 2002;
D e ry ło et al., 2003; S a d ow s ki and R y chcik, 2008). The number of dicotyledonous weeds declined between $56.3 \%$ and $70.2 \%$, while air-dry weight of weeds between $18.1 \%$ and $24.1 \%$, compared to the object in which weeds were controlled by using harrowing (Table 4). At the same time, the number of monocotyledonous weeds in the herbicide-treated plots was higher on average by $61.8 \%$ up to $133.8 \%$ than under conditions of mechanical weed control. This probably resulted from the fact that florasulam and 2,4-D EHE are substances which have an effect only on dicotyledonous weeds. While reducing their numbers, good conditions for the development of monocotyledonous taxa were created. When De ry ło et al. (2006) introduced more intensive weed control by applying a herbicide, among others, they obtained a reduction in the number of weeds per $1 \mathrm{~m}^{2}$ by $31.7 \%$ and of their air-dry weight by $15.5 \%$ compared to mechanical crop protection. In other studies (D e ryło et al. 2003), chemical protection of oat crops against weeds significantly decreased their numbers by $72 \%$ and biomass by $76 \%$ compared to mechanical protection. Moreover, the number of species was reduced by 6 as well as most dominant species were reduced. In the present experiment, the application of the herbicide Mustang 306 SE decreased the number of species by 7 in relation to the control object (Table 5). Among others, Conyza canadensis, Geranium pusillum, Stachys palustris, and Gypsophila muralis were eliminated from the crop, but single individuals of Veronica persica, Cirsium arvense, Lamium amplexicaule, and Trifolium pratense appeared. At the same time, there was a distinct decrease in the numbers of almost all the dicotyledonous species. Among the monocotyledonous species, Echinochloa crus-galli significantly increased its proportion in the community, while the remaining taxa were generally reduced compared to the control object.

In the plots which were foliar fertilized with Insol 3 and Insol 3, together with the formulation FoliCare 18:18:18, the number of dicotyledonous species was 25 and 22, respectively, whereas from the monocotyledonous group there were 5 species in each of them. Foliar feeding of plants generally intensified the occurrence of individual taxa compared to the object in which the herbicide Mustang 306 SE was used without the foliar fertilizers. This applied in particular to the dominant species such as Echinochloa crus-galli or Chenopodium album. Additionally, new species appeared in the foliar-fertilized plots, among others Geranium pusillum and Veronica agrestis. However, their proportion in the weed community was low and did not generally exceed $0.4 \%$. 
Table 2

Number and air-dry weight of weeds per $1 \mathrm{~m}^{2}$ in the oat crop depending on variety, mean for 2007-2009

\begin{tabular}{lccc}
\hline \multirow{2}{*}{ Trait } & \multicolumn{2}{c}{ Variety } & LSD $_{0.05}$ \\
\cline { 2 - 3 } & Cacko & Krezus & 10.06 \\
\hline Number of dicotyledonous weeds & 40.7 & 17.7 & 18.27 \\
Number of monocotyledonous weeds & 79.7 & 41.2 & 20.59 \\
Total number of weeds & 120.4 & 58.9 & 12.81 \\
Air-dry weight of weeds in ${\mathrm{g} \times \mathrm{m}^{-2}}^{-2}$ & 89.5 & 56.1 & \\
\hline
\end{tabular}

Table 3

Species composition and number of weeds per $1 \mathrm{~m}^{2}$ in the oat crop depending on variety, mean for 2007-2009

\begin{tabular}{|c|c|c|c|}
\hline & & & \\
\hline & weed species & Cacko & Krezus \\
\hline & Dicotyledonous & & \\
\hline 1 & Chenopodium album $\mathrm{L}$. & 6.7 & 3.6 \\
\hline 2 & Galinsoga parviflora Cav. & 6.2 & 1.0 \\
\hline 3 & $\begin{array}{l}\text { Matricaria maritima subsp. } \\
\text { inodora (L.) }\end{array}$ & 4.4 & 2.7 \\
\hline 4 & Polygonum aviculare $\mathrm{L}$. & 3.1 & 1.5 \\
\hline 5 & Stellaria media (L.) Vill. & 3.0 & 2.0 \\
\hline 6 & Viola arvensis Murray & 2.5 & 0.3 \\
\hline 7 & Amaranthus retroflexus $\mathrm{L}$. & 2.4 & 0.2 \\
\hline 8 & Plantago major $\mathrm{L}$. & 1.8 & 0.6 \\
\hline 9 & Spergula arvensis $\mathrm{L}$. & 1.1 & 0.5 \\
\hline 10 & Gnaphalium uliginosum L. & 1.1 & 0.1 \\
\hline 11 & Fallopia convolvulus L. & 1.0 & 0.9 \\
\hline 12 & Veronica arvensis $\mathrm{L}$. & 1.0 & 0.4 \\
\hline 13 & Capsella bursa-pastoris L. & 0.9 & 0.3 \\
\hline 14 & Vicia hirsuta $\mathrm{L}$. & 0.8 & 0.3 \\
\hline 15 & Geranium pusillum L. & 0.7 & 0.4 \\
\hline 16 & Anagallis arvensis $\mathrm{L}$. & 0.6 & 0.1 \\
\hline 17 & Galium aparine L. & 0.6 & 0.8 \\
\hline 18 & Gypsophila muralis L. & 0.5 & 0.2 \\
\hline 19 & Conyza canadensis $\mathrm{L}$. & 0.4 & 0.5 \\
\hline 20 & Raphanus raphanistrum $\mathrm{L}$. & 0.4 & 0.1 \\
\hline 21 & Myosotis arvensis $\mathrm{L}$. & 0.3 & 0.5 \\
\hline 22 & Vicia tetrasperma $\mathrm{L}$. & 0.2 & 0.1 \\
\hline 23 & Veronica agrestis L. & 0.2 & - \\
\hline 24 & Stachys palustris L. & 0.2 & - \\
\hline 25 & Sonchus arvensis $\mathrm{L}$. & 0.1 & - \\
\hline 26 & Cirsium arvense $\mathrm{L}$. & 0.1 & - \\
\hline
\end{tabular}

\begin{tabular}{|c|c|c|c|}
\hline & \multirow{2}{*}{ Weed species } & \multicolumn{2}{|c|}{ Variety } \\
\hline & & Cacko & Krezus \\
\hline 27 & Chamomilla suaveolens L. & 0.1 & 0.0 \\
\hline 28 & $\begin{array}{l}\text { Polygonum lapathifolium L. } \\
\text { subsp. lapathifolium }\end{array}$ & 0.1 & 0.0 \\
\hline 29 & Mentha arvensis L. & 0.1 & - \\
\hline 30 & Papaver rhoeas $\mathrm{L}$. & 0.1 & - \\
\hline 31 & Cerastium arvense $\mathrm{L}$. & 0.0 & - \\
\hline 32 & Lamium amplexicaule $\mathrm{L}$. & 0.0 & - \\
\hline 33 & Oxalis fontana Bunge & 0.0 & - \\
\hline 34 & Veronica persica Poir. & - & 0.2 \\
\hline 35 & Centaurea cyanus $\mathrm{L}$. & - & 0.1 \\
\hline 36 & Convolvulus arvensis $\mathrm{L}$. & - & 0.1 \\
\hline 37 & Anthemis arvensis $\mathrm{L}$. & - & 0.1 \\
\hline 38 & Anchusa arvensis $\mathrm{L}$. & - & 0.1 \\
\hline \multirow[t]{4}{*}{39} & Trifolium pratense $\mathrm{L}$. & - & 0.0 \\
\hline & Total dicotyledonous weeds & 40.7 & 17.7 \\
\hline & $\begin{array}{l}\text { Number of dicotyledonous } \\
\text { species }\end{array}$ & 33 & 30 \\
\hline & Monocotyledonous & & \\
\hline 40 & Echinochloa crus-galli L. & 42.6 & 12.4 \\
\hline 41 & $\begin{array}{l}\text { Setaria pumila (Poir.) Roem. } \\
\& \text { Schult }\end{array}$ & 17.7 & 10.8 \\
\hline 42 & Apera spica-venti $\mathrm{L}$. & 11.5 & 8.3 \\
\hline 43 & Elymus repens L. & 5.9 & 9.5 \\
\hline \multirow[t]{4}{*}{44} & Poa аппиа $\mathrm{L}$. & 2.0 & 0.2 \\
\hline & $\begin{array}{l}\text { Total monocotyledonous } \\
\text { weeds }\end{array}$ & 79.7 & 41.2 \\
\hline & $\begin{array}{l}\text { Number of } \\
\text { monocotyledonous species }\end{array}$ & 5 & 5 \\
\hline & Total number of weeds & 120.4 & 58.9 \\
\hline
\end{tabular}

0.0 - Species occurring in less than 0.1 per $\mathrm{m}^{2}$ 
Table 4

Number and air-dry weight of weeds per $1 \mathrm{~m}^{2}$ in the oat crop depending on weed control treatment, mean for 2007-2009

\begin{tabular}{|c|c|c|c|c|c|c|}
\hline \multirow{2}{*}{ Trait } & \multicolumn{5}{|c|}{ Weed control treatment } & \multirow{2}{*}{$\mathrm{LSD}_{0.05}$} \\
\hline & $A^{*}$ & $\mathrm{~B}$ & $\mathrm{C}$ & $\mathrm{D}$ & $\mathrm{E}$ & \\
\hline Number of dicotyledonous weeds & 49.7 & 46.7 & 13.9 & 15.8 & 20.4 & 22.38 \\
\hline Number of monocotyledonous weeds & 61.0 & 36.1 & 58.4 & 84.4 & 62.0 & 40.64 \\
\hline Total number of weeds & 110.7 & 82.8 & 72.3 & 100.2 & 82.4 & $\mathrm{~ns}^{* *}$ \\
\hline Air-dry weight of weeds in $\mathrm{g} \times \mathrm{m}^{-2}$ & 81.7 & 84.4 & 64.5 & 69.1 & 64.1 & ns \\
\hline $\begin{array}{l}\text { ns** - difference not significant } \\
\text { A* - control treatment } \\
\text { B - harrowing twice } \\
\text { C - Mustang } 306 \mathrm{SE} \\
\text { D - Mustang } 306 \mathrm{SE}+\text { Insol } 3 \\
\text { E - Mustang } 306 \mathrm{SE}+\text { Insol } 3 \text { + FoliCare } 18\end{array}$ & & & & & & \\
\hline
\end{tabular}

Table 5

Species composition and number of weeds per $1 \mathrm{~m}^{2}$ in the oat crop depending on weed control treatment, mean for 2007-2009

\begin{tabular}{|c|c|c|c|c|c|c|}
\hline \multirow[b]{2}{*}{ No. } & \multirow[b]{2}{*}{ Weed species } & \multicolumn{5}{|c|}{ Weed control treatment } \\
\hline & & $\mathrm{A}^{*}$ & $\mathrm{~B}$ & $\mathrm{C}$ & $\mathrm{D}$ & $\mathrm{E}$ \\
\hline & Dicotyledonous & & & & & \\
\hline 1 & Chenopodium album $\mathrm{L}$. & 12.5 & 9.4 & 0.1 & 1.6 & 2.2 \\
\hline 2 & Stellaria media (L.) Vill. & 5.2 & 6.1 & 0.4 & 0.6 & 0.3 \\
\hline 3 & Galinsoga parviflora Cav. & 4.5 & 5.8 & 1.6 & 1.0 & 5.1 \\
\hline 4 & $\begin{array}{l}\text { Matricaria maritima subsp. } \\
\text { inodora (L.) }\end{array}$ & 3.8 & 4.8 & 2.5 & 3.4 & 3.4 \\
\hline 5 & Plantago major L. & 3.2 & 2.0 & 0.2 & 0.2 & 0.3 \\
\hline 6 & Amaranthus retroflexus L. & 3.2 & 1.0 & 0.1 & - & 2.1 \\
\hline 7 & Polygonum aviculare L. & 2.7 & 3.1 & 3.2 & 1.5 & 1.0 \\
\hline 8 & Viola arvensis Murray & 2.4 & 1.4 & 0.7 & 1.6 & 0.9 \\
\hline 9 & Fallopia convolvulus L. & 1.9 & 1.2 & 0.4 & 0.6 & 0.5 \\
\hline 10 & Spergula arvensis $\mathrm{L}$. & 1.3 & 0.5 & 0.7 & 0.7 & 0.8 \\
\hline 11 & Conyza canadensis $\mathrm{L}$. & 1.2 & 1.0 & - & 0.2 & - \\
\hline 12 & Geranium pusillum L. & 1.2 & 0.9 & - & 0.4 & 0.2 \\
\hline 13 & Capsella bursa-pastoris L. & 1.1 & 0.6 & 0.8 & 0.4 & 0.2 \\
\hline 14 & Vicia hirsuta $\mathrm{L}$. & 1.0 & 1.0 & 0.4 & - & 0.2 \\
\hline 15 & Galium aparine L. & 1.0 & 1.8 & 0.3 & 0.2 & 0.3 \\
\hline 16 & Myosotis arvensis L. & 0.6 & 0.7 & 0.1 & 0.5 & - \\
\hline 17 & Stachys palustris L. & 0.4 & - & - & - & - \\
\hline 18 & Gypsophila muralis L. & 0.3 & 1.3 & - & - & - \\
\hline 19 & Anagallis arvensis $\mathrm{L}$. & 0.3 & 0.4 & 0.4 & 0.4 & 0.2 \\
\hline 20 & Gnaphalium uliginosum $\mathrm{L}$. & 0.2 & 1.6 & 0.2 & 0.3 & 0.7 \\
\hline 21 & Veronica arvensis L. & 0.2 & 0.6 & 1.0 & 0.8 & 0.9 \\
\hline 22 & Raphanus raphanistrum $\mathrm{L}$. & 0.2 & 0.4 & 0.1 & 0.2 & 0.3 \\
\hline 23 & Mentha arvensis L. & 0.2 & - & - & - & - \\
\hline 24 & Convolvulus arvensis L. & 0.2 & 0.1 & - & - & - \\
\hline 25 & $\begin{array}{l}\text { Polygonum lapathifolium L. } \\
\text { subsp. lapathifolium }\end{array}$ & 0.2 & 0.1 & 0.1 & - & - \\
\hline 26 & Anthemis arvensis $\mathrm{L}$. & 0.2 & - & - & - & - \\
\hline
\end{tabular}

A* Explanations as in Table 4

\begin{tabular}{|c|c|c|c|c|c|c|}
\hline \multirow{2}{*}{ No. } & \multirow{2}{*}{ Weed species } & \multicolumn{5}{|c|}{ Weed control treatment } \\
\hline & & $\mathrm{A}^{*}$ & B & $\mathrm{C}$ & $\mathrm{D}$ & $\mathrm{E}$ \\
\hline 27 & $\begin{array}{l}\text { Chamomilla suaveolens } \\
\text { Pursh }\end{array}$ & 0.1 & 0.2 & - & - & - \\
\hline 28 & Sonchus arvensis L. & 0.1 & 0.2 & - & - & 0.1 \\
\hline 29 & Vicia tetrasperma $\mathrm{L}$. & 0.1 & 0.2 & 0.1 & 0.2 & 0.2 \\
\hline 30 & Centaurea cyanus $\mathrm{L}$. & 0.1 & 0.1 & - & 0.1 & - \\
\hline 31 & Papaver rhoeas L. & 0.1 & - & - & 0.1 & - \\
\hline 32 & Veronica persica Poir. & - & 0.2 & 0.1 & 0.1 & - \\
\hline 33 & Cirsium arvense $\mathrm{L}$. & - & - & 0.2 & - & 0.2 \\
\hline 34 & Lamium amplexicaule $\mathrm{L}$. & - & - & 0.1 & - & - \\
\hline 35 & Trifolium pratense $\mathrm{L}$. & - & - & 0.1 & - & - \\
\hline 36 & Veronica agrestis L. & - & - & - & 0.4 & 0.2 \\
\hline 37 & Anchusa arvensis $\mathrm{L}$. & - & - & - & 0.2 & - \\
\hline 38 & Oxalis fontana Bunge & - & - & - & 0.1 & - \\
\hline \multirow[t]{4}{*}{39} & Cerastium arvense $\mathrm{L}$. & - & - & - & - & 0.1 \\
\hline & Total dicotyledonous weeds & 49.7 & 46.7 & 13.9 & 15.8 & 20.4 \\
\hline & $\begin{array}{l}\text { Number of dicotyledonous } \\
\text { species }\end{array}$ & 31 & 28 & 24 & 25 & 22 \\
\hline & Monocotyledonous & & & & & \\
\hline 40 & Echinochloa crus-galli L. & 21.4 & 11.9 & 29.7 & 41.0 & 33.5 \\
\hline 41 & $\begin{array}{l}\text { Setaria pumila (Poir.) } \\
\text { Roem. \& Schult }\end{array}$ & 20.5 & 9.5 & 12.5 & 17.5 & 11.2 \\
\hline 42 & Elymus repens $\mathrm{L}$. & 9.8 & 7.6 & 8.8 & 6.0 & 6.4 \\
\hline 43 & Apera spica-venti $\mathrm{L}$. & 8.6 & 6.2 & 6.8 & 18.7 & 9.0 \\
\hline \multirow[t]{4}{*}{44} & Poа аппиа $\mathrm{L}$. & 0.7 & 0.9 & 0.6 & 1.2 & 1.9 \\
\hline & $\begin{array}{l}\text { Total monocotyledonous } \\
\text { weeds }\end{array}$ & 61.0 & 36.1 & 58.4 & 84.4 & 62.0 \\
\hline & $\begin{array}{l}\text { Number of monocotyledo- } \\
\text { nous species }\end{array}$ & 5 & 5 & 5 & 5 & 5 \\
\hline & Total number of weeds & 110.7 & 82.8 & 72.3 & 100.2 & 82.4 \\
\hline
\end{tabular}




\section{CONCLUSIONS}

1. The husked variety Krezus proved to be more competitive against weeds. Number of dicotyledonous weeds and of monocotyledonous weeds, total weeds, and air-dry weight of above-ground parts of weeds in the crop of this variety were all significantly lower compared to the naked variety Cacko.

2. In the crops of the oat varieties in question, Chenopodium album, Galinsoga parviflora, Matricaria maritima ssp. inodora, Polygonum aviculare, and Stellaria media were the dominant species from the group of dicotyledonous species, while Echinochloa crus-galli, Setaria pumila, Apera spica-venti, and Elymus repens among the monocotyledonous species.

3. In-crop harrowing, though it significantly reduced the number of monocotyledonous weeds, proved to be less effective in the reduction of air-dry weight of above-ground parts of weeds compared to chemical weed management.

4. More intensive weed control, in which the herbicide Mustang 306 SE was applied, reduced the number of dicotyledonous weeds (in particular the dominant species) and air-dry weight of weeds relative to the control object without herbicide protection. At the same time, the number of weed species decreased in the herbicide-treated plots (between 6 and 9), while the taxa such as, among others, Gypsophila muralis, Convolvulus arvensis, or Chamomilla suaveolens were eliminated.

5. Foliar feeding of plants with the foliar fertilizers Insol 3 and FoliCare 18:18:18 generally intensified the occurrence of individual weed taxa compared to the object in which the herbicide Mustang 306 SE was applied without the foliar fertilizers. Weed species such as, among others, Polygonum aviculare, Capsella bursa-pastoris, Vicia hirsuta, Anagallis arvensis, Veronica arvensis were an exception.

\section{REFERENCES}

Adamiak E., Adamiak J., 2004. Effect of varied crop sequence and chemical control of the stand on weed infestation of oat. Acta Sci. Pol. Agricult. 3 (1): 119-128.

Adamiak E., Zawiślak K., 1991. Fitocenozy chwastów owsa uprawianego w płodozmianie i wieloletniej monokulturze. Synteza i perspektywa nauki o płodozmianach. / Weed phytocoenoses of oat cultivated in crop rotation and in long term monoculture. Synthesis and prospect of crop rotation science. Cz. II, Wyd. ART Olsztyn: 207-214 (in Polish)

Budzyński W., 1999. Ten years of studies on oat cultivation in Poland: a review. Żywność, Supl. 1 (18): 11-25.

Deryło S., Szymankiewicz K., Grotkowska Z., Stachowska J., 2003. Weed infestation of oats at a rotation and at a multispecies monoculture of small grain crops. Biul. IHAR, 229: 73-84.

Hyvönen T., Salonen J., 2002. Weed species diversity and community composition in cropping practices at two intensity levels - a six-year experiment. Plant Ecology, 154: 73-81.

Idziak R., Michalski T., Osiecka B., 2007. Weed infestation and yielding of spring barley - Atos mixtures under differentiated plant protection conditions. Zesz. Probl. Post. Nauk Rol. 516: 55-63.

K rawczyk R., Stachecki S., 2003. Sensitivity of common oats (Avena sativa) to selected herbicides controlling monocotyledonous weeds in cereals. Prog. Plant Protect. 43 (2): 755-757.

Leszczyńska D., 2002. Uprawa owsa nieoplewionego - stan obecny i przyszłość / Cultivation of naked oat - the current state and the future. Pam. Pul. 130: 463469 (in Polish).

Leszczyńska D ., 2007. Znaczenie owsa nagoziarnistego i elementy jego agrotechniki / The imporatnce of naked oat and elements of agronomical practices used in its cultivation. Studia i Raporty IUNG-PIB, 9: 89-98 (in Polish).

Sadowski T., Rychlik B., 2008. Comparison of chemical and mechanical weed control in oat. Prog. Plant Protect. 48 (2): 656-659.

Skrzypczak G., Pudełko J., 2001. Assessment of weed control efficacy of herbicides in naked oats (Avena sativa var. nuda). Prog. Plant Protect. 41 (2): 910912.

Sułek A., Brzóska F., 2007. Uprawa i wykorzystanie owsa. Wyd. IUNG, Puławy (in Polish).

Vanhala P., Pietola L., 2003. Effect of conservation tillage and peat application on weed infestation on a clay soil. Agricult. Food Sc. Finland, 12: 133-145.

Zawiślak K., Grejner M., 1988. Community of weeds in the cereal monocultures and the chemical weed-killing efficiency. Roczniki Nauk Rol. ser. A. 107 (3): 135-146.

\section{Wpływ poziomu agrotechniki na zachwaszczenie zasiewów nagoziarnistej i oplewionej odmiany owsa (Avena sativa $L_{\text {.) }}$}

\section{Streszczenie}

Doświadczenie polowe przeprowadzono w latach 2007-2009 w Gospodarstwie Doświadczalnym Bezek koło Chełma. Celem badań było porównanie zachwaszczenia łanów oplewionej (Krezus) i nagoziarnistej (Cacko) odmiany owsa uprawianych w zróżnicowanych warunkach agrotechnicznych. Uwzględniono następujące poziomy agrotechniki: a - obiekt kontrolny; $\mathrm{b}$ - dwukrotne bronowanie; $\mathrm{c}$ - herbicyd Mustang 306 SE; d-Mustang 306 SE + nawóz dolistny 
Insol 3; e - Mustang $306 \mathrm{SE}+$ nawozy dolistne Insol 3 i FoliCare 18:18:18.

Bardziej konkurencyjna wobec chwastów była oplewiona odmiana Krezus. Zarówno liczba chwastów dwuliściennych, jednoliściennych i ogółem, jak i powietrznie sucha masa części nadziemnych chwastów w łanie tej odmiany były istotnie mniejsze w porównaniu $\mathrm{z}$ chwastami w łanie nagoziarnistej odmiany Cacko. Chwastami dominującymi w łanach porównywanych odmian owsa były Chenopodium album,
Galinsoga parviflora, Matricaria maritima ssp. inodora, Polygonum aviculare i Stellaria media z grupy chwastów dwuliściennych, natomiast z jednoliściennych Echinochloa crus-galli, Setaria pumila, Apera spica-venti $i$ Elymus repens. Wyższy poziom agrotechniki uwzględniający zastosowanie herbicydu $\mathrm{Mu}-$ stang 306 SE obniżył liczbę chwastów dwuliściennych i powietrznie suchą masę chwastów w odniesieniu do obiektu z mechanicznym pielęgnowaniem roślin. 


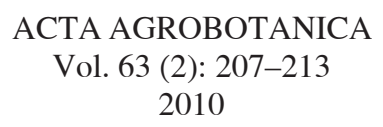

\section{ACTA AGROBOTANICA \\ Vol. 63 (2) \\ 2010}

\section{AUTHOR INDEX}

Chudzik Barbara, Szczuka Ewa, Domaciuk Marcin, Pavlov Danail: The structure of the ovule of Sida hermaphrodita (L.) Rusby after pollination

Elżbieta Weryszko-Chmielewska, Anna Matysik-Woźniak, Dagmara Sadowska: The structure and distribution of glandular trichomes on the stems and leaves of drug eyebright (Euphrasia stricta D. Wolff ex J. F. Lehm.)

Mirosława Chwil: The structure of some floral elements and the nectar production rate of Polemonium caeruleum $\mathrm{L}$.

Beata Żuraw,Elżbieta Weryszko-Chmielewska, Halina Laskowska, Elżbieta Pogroszew$\mathrm{ska}$ : The location of nectaries and nectar secretion in the flowers of Allium giganteum Regel

33

Elżbieta Weryszko-Chmielewska, Mirosława $\mathrm{Chwil:}$ Ecological adaptations of the floral structures of Galanthus nivalis L.

Magdalena Kucewicz, Ewa Gojło, Anna Kowal$\mathrm{ska}$ : The effect of achene heteromorphism on progeny traits in the shaggy soldier [Galinsoga ciliata (Rafin) S. F. Blake]

51

Magdalena Pogorzelec: The species richness of the flora of selected sections of the Mietiułka river in the Polesie National Park

57

Katarzyna Jabłońska, Piotr Rapiejko: Using the results of a nationwide phenological network to examine the impact of changes in phenology of plant species on the concentration of plant pollen in the air.

69

Katarzyna Dąbrowska-Zapart: Types of hazel (Corylus spp.) and alder (Alnus spp.) pollen seasons in Sosnowiec 1997 - 2007 (Poland)

Dorota Myszkowska: The grass pollen season dynamics in relation to the meteorological conditions in Cracow, southern Poland, 1991-2008

85

Małgorzata Malkiewicz, Kamilla Klaczak: Pollen concentrations of some plants in the air over Olszanica (Bieszczady Niskie Mountains) and Wrocław in the 2008 season

Adam Okorski, Jacek Olszewski, Katarzyna Głowacka, Sylwia Okorska, Agnieszka Pszczółkowska: The effect of the application of the biological control agent EM1 on gas exchange pa- rameters and productivity of Pisum sativum L. infected with Fusarium oxysporum Schlecht. 105

Joanna Ciszewska-Marciniak, Małgorzata Jędryczka, Stanisław Jeżowski, Jerzy Przyborowski, Katarzyna Wojciechowicz, Elżbieta Zenkteler: Morphology of uredinia and urediniospores of the fungus Melampsora larici-epitea Kleb. a damaging pathogen of common osier (Salix viminalis L.) in Poland

Agnieszka Pszczółkowska, Gabriel Fordoński, Jacek Olszewski, Tomasz Kulik, Iwona Konopka: Productivity and seed health of husked oats (Avena sativa L.) grown under different soil moisture conditions

127

Joanna Katarzyna Jarmołkowicz, Jacek Olszewski: Gas exchange parameters in leaves and ears of winter wheat Tricitum aestivum and its productivity under fungicide control conditions

135

Małgorzata Materska, Irena Perucka: Accumulation of phenylpropanoids in green and red pepper fruits of semi-hot cultivars Capsicum annuum L. $\quad 149$

Beata Janowska, Roman Andrzejak: Effect of gibberellic acid spraying and soaking of rhizomes on the growth and flowering of calla lily (Zantedeschia Spreng.)

155

Edward Borowski: The effect of the method of application and concentration of Asahi SL on the response of cucumber plants to chilling stress.

161

A leksandra Głowacka: Changes in weed infestation of common bean (Phaseolus vulgaris L.) under conditions of strip intercropping and different weed control methods

171

Cezary Kwiatkowski: Evaluation of yield quality and weed infestation of common valerian (Valeriana officinalis L.) in dependence on weed control method and forecrop

179

Teresa Skrajna, Maria Ługowska: Stubble field plant communities of the Mazowiecki Landscape Park

189

Sylwia Andruszczak, Ewa KwiecińskaPoppe, Piotr Kraska, Edward Pałys: The effect of different agrotechnical levels on weed infestation in crops of naked and husked varieties of oat (Avena sativa $\mathrm{L}$.) 
